\author{
KAZIMIERZ BANDARZEWSKI \\ ORCID: 0000-0002-8783-8820 \\ Uniwersytet Jagielloński \\ [Brak adresu e-mail]
}

\title{
Udział izb gospodarczych w decentralizacji władzy publicznej
}

\begin{abstract}
Abstrakt: Izby gospodarcze stanowią organizację zrzeszającą przedsiębiorców, będącą według ustawy formą samorządu gospodarczego. Samorząd ten, w przeciwieństwie do samorządu terytorialnego, ma zróżnicowaną postać. Zawarta w art. 17 ust. 2 Konstytucji RP regulacja samorządu gospodarczego nie pozwala na jego zakwalifikowanie do kategorii podmiotów prawa publicznego i nie można go uznać za formę decentralizacji władzy publicznej. Nie stanowi to przeszkody przed sporadycznym przekazywaniem izbom gospodarczym zadań publicznych.
\end{abstract}

Słowa kluczowe: decentralizacja, samorząd terytorialny, samorząd gospodarczy, izby gospodarcze, Krajowa Izba Gospodarcza.

\section{Wprowadzenie}

W jednej z istotniejszych prac w dwudziestowiecznej nauce polskiej dotyczącej problematyki instytucji samorządu terytorialnego, zatytułowanej Zwiazki publiczno-prawne w świetle ustawodawstwa polskiego ${ }^{1}$, Profesor Tadeusz Bigo część miejsca poświęcił ówczesnym organizacjom izb przemysłowo-handlowym. Wynikało to z obowiązującej regulacji konstytucyjnej ${ }^{2}$ zakładającej włączenie samorządu gospodarczego w strukturę podmiotów będących związkami publicznoprawnymi ${ }^{3}$.

1 T. Bigo, Zwiazki publiczno-prawe w świetle ustawodawstwa polskiego, Warszawa 1928, s. $56,64-67,100-102$.

2 Art. 68 ustawy z 17 marca 1921 roku Konstytucja Rzeczypospolitej Polskiej (Dz.U. z 1921 r. $\mathrm{Nr} 44$, poz. 267 z późn. zm.).

3 T. Bigo, op. cit., s. 51, s. 70-71; K. Dąbrowski, Izby przemystowo-handlowe Drugiej Rzeczypospolitej jako instytucja samorządu przemysłowo-handlowego. Ujęcie doktrynalne i konstytucyjne, „Studia z Dziejów Państwa i Prawa Polskiego”, t. 10, Kraków-Lublin-Łódź 2007, s. 306-308. 
Trwałym wkładem w naukę polską zapisała się wyrażona w wyżej wymienionej publikacji istota związku publicznoprawnego, zgodnie z którą jest nią posługiwanie się przez wyodrębniony podmiot władztwem administracyjnym polegającym na możliwości stosowania przymusu administracyjnego i wykluczeniu drogi sądowej w sporach między takim związkiem a jego członkami, a także powoływanie takiego związku przez państwo lub przy jego udziale 4 .

Niewątpliwie od czasów, w których Profesor Tadeusz Bigo pisał swoje dzieło, zmienił się system nie tylko prawny, ale także społeczny, gospodarczy i polityczny. Tym niemniej nadal pozostaje kwestą otwartą, czy wykonywanie władzy publicznej powinno być skupione przede wszystkim na administracji samorządowej i rządowej, czy też należałoby „dopuścić” do tej dychotomicznej struktury także samorząd gospodarczy (izby gospodarcze).

Celem niniejszego artykułu będzie przedstawienie normatywnego modelu samorządu gospodarczego oraz możliwości jego udziału w wykonywaniu zadań publicznych, przy czym analizą zostanie pominięta Polska Izba Ubezpieczeń stanowiąca wyjątkowy w prawie polskim przykład obligatoryjnego samorządu gospodarczego w prawie polskim ${ }^{5}$.

\section{Pojęcie decentralizacji}

Podstawowym pojęciem opisującym w polskim systemie prawnym udział innych struktur niż administracji rządowa w wykonywaniu władzy publicznej jest decentralizacja.

Profesor Tadeusz Bigo zdefiniował decentralizację (ściślej ujmując: decentralizację prawno-administracyjną) jako taki system organów, w którym podmioty administrujące mają samodzielność w stosunku do centrum władzy i nie podlegają hierarchicznemu podporządkowaniu ${ }^{6}$. Definicja ta pozostaje aktualna także współcześnie. Wskazuje się, że decentralizacją jest ustalony przez prawo pewien stopień samodzielności w wykonywaniu określonych zadań przez jednostkę zdecentralizowaną. Jest to samodzielność względna, ponieważ jej granice w działaniach organów wykonujących zadania wyznaczają środki nadzoru oraz podmiot kreujący zadania publiczne dla samorządu ${ }^{7}$. Decentralizacja zakłada brak hierarchicznego podporządkowania dyrektywom organów nadrzędnych wobec jed-

4 T. Bigo, op. cit., s. 80-85, 116-119.

5 Art. 422 ust. 1 ustawy z dnia 11 września 2015 roku o działalności ubezpieczeniowej i reasekuracyjnej (Dz.U. z 2020 r. poz. 895 ze zm.).

6 T. Bigo, op. cit., s. 120-123.

7 M. Stahl, Zagadnienia ogólne, [w:] System Prawa Administracyjnego, t. 6. Podmioty administrujące, red. R. Hauser, Z. Niewiadomski, A Wróbel, Warszawa 2011, s. 84-88; J. Boć, Decentralizacja, [w:] Prawo administracyjne, red. J. Boć, Wrocław 2001, s. 225-228. 
nostek zdecentralizowanych oraz brak możliwości ingerencji organu wyższego szczebla w działalność organu szczebla niższego ${ }^{8}$.

Definiując decentralizację, nie możemy pominąć jej regulacji zawartej w art. 15 ust. 1 Konstytucji Rzeczypospolitej Polskiej (dalej: Konstytucja RP) ${ }^{9}$. Przepis ten wskazuje, że decentralizacja władzy publicznej jest zapewniona (zagwarantowana) poprzez ustrój terytorialny. Ustrój terytorialny Polski stanowi jeden z elementów szerszego pojęcia, czyli wskazanego w art. 10 Konstytucji RP ustroju Rzeczypospolitej Polski. Tym samym, skoro ustrój Rzeczypospolitej Polskiej dotyczy władzy publicznej, jej podziału i wzajemnych relacji (opartych na ich równowadze $)^{10}$, to także ustrój terytorialny winien dotyczyć którejś z wyżej wymienionych władz w odniesieniu do szczebla terytorialnego (terenowego).

Terytorialny podział władzy obejmuje dwa podstawowe aspekty: po pierwsze, kryteria samego podziału, po drugie, funkcje (charakter) władzy terenowej. Pierwszy z nich wprost rozwija Konstytucja RP w art. 15 ust. 2, stanowiąc, że zasadniczy podział terytorialny państwa ma uwzględniać więzi społeczne, gospodarcze lub kulturowe i zapewniać jednostkom terytorialnym zdolność wykonywania zadań publicznych. Poprzez zaakcentowanie więzi jako podstawy to tworzenia zasadniczego podziału terytorialnego ustrojodawca wprost wskazuje, że zasadniczo podział terytorialny to podział oparty o wspólnoty mieszkańców ${ }^{11}$. Potwierdza to art. 16 ust. 1 i 2 Konstytucji RP, wskazując, że zasadniczy podział terytorialny państwa dotyczy wyłącznie wspólnot samorządowych, a wspólnoty te, stanowiąc samorząd terytorialny, uczestniczą w sprawowaniu władzy publicznej.

Art. 16 ust. 2 zdanie drugie Konstytucji RP reguluje drugi aspekt ustroju terytorialnego, mianowicie funkcję władzy wykonywanej terytorialnie. Zgodnie z tym przepisem sprawowanie przez samorząd terytorialny władzy publicznej oznacza, że samorząd ten wykonuje w imieniu własnym i na własną odpowiedzialność przysługującą mu w ramach ustaw istotną część zadań publicznych. Z powyższego wynika, że samorząd terytorialny jest częścią władzy wykonawczej, dla której zadania określa tylko ustawodawca ${ }^{12}$.

Rekapitulując ten fragment rozważań, musimy stwierdzić, że pojęcie decentralizacji wynikającej z art. 15 ust. 1 Konstytucji RP oznacza przekazanie przez ustawodawcę jednostkom samorządu terytorialnego władzy wykonawczej obejmującą istotną część zadań publicznych, przy czym zadania te są wykonywane we

${ }^{8}$ P. Tuleja, [w:] Konstytucja Rzeczypospolitej Polskiej. Komentarz, red. P. Tuleja, Warszawa 2019, teza nr 1 do art. 15; M. Wierzbowski, A. Wiktorowska, Decentralizacja i centralizacja administracji, [w:] Prawo administracyjne, red. M. Wierzbowski, Warszawa 2008, s. 95-97.

${ }^{9}$ Ustawa z dnia 2 kwietnia 1997 roku Konstytucji Rzeczypospolitej Polskiej (Dz.U. z 1997 r. $\mathrm{Nr} 78$, poz. 483 ze zm.).

10 W. Skrzydło, Konstytucja Rzeczypospolitej Polskiej. Komentarz, LEX 2013, komentarz do art. 10 .

11 Wyrok TK z dnia 26 lutego 2003 roku, sygn. K 30/02, OTK-A 2003/2/16.

12 P. Tuleja, op. cit., teza $\mathrm{nr} 2$ do art. 15. 
własnym imieniu i na własną odpowiedzialność struktur zasadniczego podziału, a więc ze wskazaniem przez ustawodawcę jakiegoś zakresu samodzielności ${ }^{13}$.

Tak definiowana decentralizacja dotyczy przede wszystkim samorządu terytorialnego. Czy definicja ta ma charakter uniwersalny i powinna być stosowana także do samorządu gospodarczego? Nie budzi wątpliwości, że doktrynalna definicja decentralizacji akcentująca wykonywanie zadań publicznych w granicach przyznanej samodzielności obejmuje także samorząd gospodarczy.

Wydaje się, że także konstytucyjne ujęcie decentralizacji można odnieść do samorządu gospodarczego. Wprawdzie samorząd gospodarczy, w przeciwieństwie do terytorialnego, stanowi korporację przedsiębiorców, tym niemniej tworzenie jego struktur mogłoby być oparte na istniejącym ustroju zasadniczego podziału kraju, jeżeli nie od szczebla gmin, to z pewnością od szczebla powiatu (wraz z miastami na prawach powiatu). Tym samym wpisanie samorządu gospodarczego w zasadniczy podział terytorialny kraju byłoby realne nawet bez wykorzystania każdego szczebla. Odrębną kwestią byłaby efektywność takiego podziału na potrzeby samorządu gospodarczego. Wydaje się również, że podział ten uwzględniałby także więzi między przedsiębiorcami mającymi swoje siedziby na terenie na przykład danego powiatu, a w szczególności więzi gospodarcze.

W związku z powyższym należy twierdzić, że także samorząd gospodarczy nie tylko w ujęciu teoretycznym stanowi jedną z form decentralizacji władzy publicznej, ale także i art. 15 Konstytucji RP nie stanowiłby przeszkody, aby struktury tego samorządu tworzone na podstawie struktur zasadniczego podziału terytorialnego kraju mogły być uznane jako forma decentralizacji władzy publicznej.

\section{Izby gospodarcze jako forma samorządu gospodarczego}

Definicję izby gospodarczej zawiera art. 2 ustawy o izbach gospodarczych (dalej: u.i.g. $)^{14}$. Zgodnie z tym przepisem izba gospodarcza jest organizacją samorządu gospodarczego reprezentującą interesy gospodarcze zrzeszonych w niej przedsiębiorców, w szczególności wobec organów władzy publicznej. Poza reprezentacją, kolejnymi celami działania izb gospodarczych są: 1) kształtowanie i upowszechnianie zasad etyki w działalności gospodarczej, w szczególności opracowywanie i doskonalenie norm rzetelnego postępowania w obrocie gospodarczym (art. 3 u.i.g.); 2) wyrażanie opinii o projektach rozwiązań odnoszących się do funkcjonowania gospodarki oraz możliwość uczestniczenia, na zasadach określonych $\mathrm{w}$ odrębnych przepisach, w przygotowywaniu projektów aktów prawnych w tym zakresie (art. 4 ust. 1 u.i.g.); 3) dokonywanie ocen wdrażania

13 Wyrok TK z dnia 18 lutego 2003 roku, sygn. K 24/02, OTK-A 2003/2/11.

14 Ustawa z dnia 30 maja 1989 roku o izbach gospodarczych (Dz.U. z 2019 r. poz. 579). 
i funkcjonowania przepisów prawnych dotyczących prowadzenia działalności gospodarczej (art. 4 ust. 2 u.i.g.).

Wątpliwości wywołuje zdefiniowanie przez ustawodawcę izby gospodarczej jako organizacji samorządu gospodarczego. W orzecznictwie sądowym nie ma jednolitego poglądu na temat zakwalifikowania izb gospodarczych do kategorii organizacji społecznych lub jednostek samorządu gospodarczego. Wydaje się jednak przeważać pogląd, zgodnie z którym izby gospodarcze nie są organizacjami społecznymi, ale organizacjami samorządu gospodarczego zrzeszającymi przedsiębiorców, powołanymi do obrony interesów własnych członków ${ }^{15}$. Odmienne poglądy traktujące izby gospodarcze jako organizacje społeczne znajdują się w mniejszości ${ }^{16}$.

W doktrynie natomiast wydaje się zdecydowanie przeważać stanowisko przeciwko uznaniu izb gospodarczych za organizacje samorządu. Podnosi się bowiem, że z analizy ustawowo określonych zadań tych izb nie wynika, aby wypełniały one jakiekolwiek funkcje z zakresu administracji publicznej, a przy tym już fakultatywność członkostwa w izbach pozbawia je cech samorządu ${ }^{17}$.

Dominuje pogląd, zgodnie z którym uznanie samorządu gospodarczego za samorząd $\mathrm{w}$ ujęciu publicznoprawnym wymaga spełnienia następujących cech: a) wykonywanie przekazanych przez prawodawcę zadań publicznych; b) możliwość samodzielnego wykonywania tych zadań w sposób uwzględniający potrzeby przedsiębiorców; c) obecność organów wybieranych w powszechnych wyborach ${ }^{18}$. Dodatkowo podnosi się kwestię obligatoryjnego członkostwa przedsiębiorców w samorządzie gospodarczym ${ }^{19}$.

Traktowanie samorządu gospodarczego jedynie jako samorządu o obligatoryjnym członkostwie wszystkich przedsiębiorców, wykonujących na ich rzecz określone zadania publiczne jest metodologicznie poprawne, ale nie odnosi się do

15 Wyrok NSA z dnia 10 stycznia 2012 roku, sygn. II FSK 1330/10, LEX nr 1125422; wyrok NSA z dnia 3 marca 2015 roku, sygn. II FSK 1933/13, LEX nr 1666132.

16 Por. wyrok NSA z dnia 15 marca 2017 roku, sygn. II OSK 1864/15, LEX nr 2316638; wyrok NSA z dnia 14 listopada 2018 roku, sygn. II OSK 499/17, LEX nr 2651532.

17 T. Jastrzębski, Samorząd gospodarczy. Izba Domów Składowych, „Przegląd Ustawodawstwa Gospodarczego" 2004, nr 10, s. 83-84; M.A. Waligórski, Izby samorządu gospodarczego, [w:] Prawo administracyjne ustrojowe. Podmioty administracji publicznej, red. J. Stelmasiak, J. Szreniawski, Bydgoszcz-Lublin 2002, s. 94-95; S. Biernat, Administracyjnoprawne zasady podejmowania dziatalności gospodarczej (de lege lata $i$ de lege ferenda), [w:] Księga Pamiatkowa Profesora Eugeniusza Ochendowskiego, Toruń 1999, s. 50; R. Kmieciak, P. Antkowiak, K. Walkowiak, Samorzą gospodarczy i zawodowy w systemie politycznym Polski, Warszawa 2012, s. 150-151; K. Bandarzewski, Samorzad gospodarczy w prawie polskim. Studium prawne, Kraków 2014, s. 211; K. Sikora, Izby rolnicze jako forma samorzadu gospodarczego w Polsce, „Studia Iuridica Lublinensia” 17, 2012, s. 109-112, 130-133.

18 R. Kmieciak, Pozycja ustrojowa samorzadu gospodarczego w Polsce, „Studia z Polityki Publicznej" 3, 2016, nr 2 (10), s. 91.

19 M. Błachucki, Przemiany ustrojowe samorzadu specjalnego w polskim prawie administracyjnym, [w:] Prace stadialne Warszawskiego Seminarium Aksjologii Administracji, t. 3, Kraków 2014, s. 23-24. 
specyfiki tej formy samorządu. Samo pojęcie samorządu gospodarczego — w odróżnieniu od pojęcia samorządu terytorialnego - nie jest bowiem jednolite i nie jest identycznie postrzegany $w$ nauce innych państw ${ }^{20}$. Pośród czterech generalnych modeli samorządu gospodarczego: kontynentalnego (francuskiego), anglosaskiego, mieszanego i administracyjnego ${ }^{21}$ nie ma zgodności zarówno co podstawowego zakresu i charakteru ich zadań, jak i członkostwa w takich strukturach. Model francuski (kontynentalny) samorządu traktuje go jako obligatoryjną część administracji terenowej wykonującej zadania publiczne na rzecz i wobec przedsiębiorców ${ }^{22}$; taki właśnie model jest w nauce polskiej traktowany jako właściwy.

Natomiast koncepcja anglosaska samorządu gospodarczego statuuje go jako organizację prawa prywatnego, skupiającą się na reprezentowaniu członków tworzących takie struktury i pomaganiu w prowadzeniu działalności gospodarczej ${ }^{23}$. Model mieszany samorządu stanowi połączenie koncepcji samorządu przymusowego (model francuski) i samorządu dobrowolnego (model anglosaski). Koncepcja administracyjna traktuje samorząd jako część administracji rządowej, wykonującej zadania rządowe wobec samorządu, przybierającej postać albo odrębnej administracji rządowej, albo agencji rządowej, w skład których nie wchodzą przedsiębiorcy ${ }^{24}$.

Wielość koncepcji samorządu gospodarczego stanowi podstawę do stwierdzenia, że wyeliminowanie a limine dopuszczalności nazwania w art. 2 u.i.g. izb gospodarczych jako formy samorządu gospodarczego nie jest uzasadnione. Nie ma bowiem jednolitej koncepcji samorządu gospodarczego i nie ma potrzeby w dążeniu do jednolitości. Samorząd gospodarczy uregulowany w ustawie o izbach gospodarczych jest najbliższy koncepcji anglosaskiej samorządu (a w szczególności jej tak zwanej wersji belgijskiej, polegającej na tym, że organizacje samorządu tworzone są jako stowarzyszenia) ${ }^{25}$.

\section{Dopuszczalność udziału izb gospodarczych w decentralizacji}

Rozważania na temat udziału izb gospodarczych w decentralizacji władzy publicznej należałoby rozpocząć od analizy art. 17 ust. 2 Konstytucji RP. Samo

20 P. Bilancia, F. Pizzetii, Chambers of Commerce in Italy and in some European Union Countries: a study of functional and autonomous bodies, Roma 2000, s. 74-79.

${ }^{21} \mathrm{~K}$. Bandarzewski, op. cit., s. 279-291.

22 Ibidem, s. 280-284.

23 Ibidem, s. 285-287.

24 Ibidem, s. 289.

25 Ibidem, s. 285; S. Pawłowski, Samorzad (organizacje) pracodawców, [w:] Samorzad zawodowy i gospodarczy, red. M.A. Waligórski, S. Pawłowski, Poznań 2005, s. 303-308. 
umiejscowienie art. 17 jest symptomatyczne. Artykuł ten jest kolejny po zawartej w art. 15-16 Konstytucji RP regulacji konstytucyjnych podstaw funkcjonowania samorządu terytorialnego, będącego, co nie ulega wątpliwości, podstawową formą decentralizacji władzy publicznej. Ponadto, zgodnie z art. 17 ust. 1 Konstytucji RP formą decentralizacji władzy publicznej jest samorząd zawodowy. Tym samym logiczne byłoby, aby art. 17 ust. 2 ustawy zasadniczej regulujący inne rodzaje samorządu także wskazywał samorząd jako formę decentralizacji. Gdyby samorząd (inny niż terytorialny lub zawodowy) nie miał być formą decentralizacji władzy publicznej, to wystarczającą konstytucyjną podstawą jego funkcjonowania byłby art. 12 Konstytucji RP, zgodnie z którym zapewnia się wolność tworzenia i działania związków zawodowych, organizacji społeczno-zawodowych rolników, stowarzyszeń, ruchów obywatelskich, innych dobrowolnych zrzeszeń oraz fundacji oraz art. 58 Konstytucji RP zawierającym wolność zrzeszania się w różnorodne organizacje.

Logiczne więc wydaje się, że inne rodzaje samorządu, o których stanowi art. 17 ust. 2 Konstytucji RP miały być w zamierzeniu ustrojodawcy kolejną formą decentralizacji. Dodatkowo można podnieść, że skoro w nauce polskiej pojęcie samorządu implikuje traktowanie go jako formy publicznoprawnej wykonywania zadań publicznych, to zasadnym było uregulowanie tego samorządu właśnie $\mathrm{w}$ art. 17 Konstytucji RP.

Jednakże analiza treści art. 17 ust. 2 Konstytucji RP prowadzi do wniosku, że inne samorządy niż terytorialny lub zawodowy nie mogą być zaliczone do formy decentralizacji władzy publicznej, i to mimo że regulacja art. 15 ustawy zasadniczej nie sprzeciwiałaby się takiemu zakwalifikowaniu tego samorządu.

Zgodnie z art. 7 Konstytucji RP każdy organ władzy publicznej działa na podstawie i w granicach prawa, co wyklucza stosowanie domniemania zarówno kompetencji jak i zadań takich organów. Tylko takie podmioty wykonują władzę publiczną, które zostaną wskazane wprost we właściwych przepisach, czyli przepisach rangi konstytucyjnej, ponieważ to Konstytucja RP określa ustrój państwa, a więc i podstawowe struktury władzy. Przepisy konstytucyjne wprost zakwalifikowały samorząd terytorialny i zawodowy do udziału we władzy wykonawczej, określając ich zadania.

Natomiast samorząd gospodarczy został objęty art. 17 ust. 2 zd. 1 Konstytucji RP nawet bez określenia jego nazwy poprzez zakwalifikowanie go do kategorii „,innych rodzajów samorządu”. Mogłoby się wydawać, że w ujęciu konstytucyjnym jest jedna formuła „samorządu” z podziałem na jego rodzaje. Takim rodzajem byłby samorząd terytorialny, samorząd zawodowy i inne rodzaje samorządu. Gdyby przyjąć taką konstrukcję, to jej konsekwencją byłaby wewnętrzna sprzeczność samej regulacji art. 15-17 Konstytucji RP. Oto ustrojodawca odrębnie zdefiniował samorząd terytorialny i samorząd zawodowy, wprost wskazując, że mają one charakter korporacji terytorialnej i zawodowej ze wskazaniem na zakres za- 
dań publicznych do wykonywania, natomiast pozostałe rodzaje samorządu (to jest gospodarczy) nie posiadałyby żadnego konstytucyjnego umocowania do udziału we władzy publicznej.

Można przyjąć inny sposób wykładni art. 17 ust. 2 Konstytucji RP, który nie prowadzi do sprzeczności wyżej wskazanych przepisów. Inne rodzaje samorządu, o których stanowi art. 17 ust. 2 Konstytucji RP, dotyczą jakiejkolwiek innej formuły samorządu niezależnie od tego, czy samorząd ten, jak w przypadku gospodarczego, oparty jest o koncepcję anglosaską wykluczającą co do zasady uznanie jego struktury za część władzy wykonawczej (podmiotu administracji publicznej), czy też inne jeszcze formy samorządu (na przykład rolniczego). Tym samym wydaje się zasadnym zaakcentowanie określenia „rodzaj” jako tego elementu, który odróżnia samorząd terytorialny, zawodowy od innych rodzajów samorządu. Pod pojęciem rodzaju będzie można określić różne formuły samego pojęcia samorządu.

Tym samym prowadzi to do swoistego powrotu do dylematu zawartego w pracy Profesora Tadeusza Bigi, w której analizowano istotę organizacji noszącej nazwę ,samorząd” celem wyodrębnienia samorządu w znaczeniu podmiotu prawa publicznego i samorządu w znaczeniu organizacji prywatnoprawnej. Na podstawie art. 17 ust. 2 Konstytucji RP owo zróżnicowanie także zostało zaakcentowane i skupia się na pojęciu „rodzajów” samorządu.

Powyższe pozwala na objęcie pojęciem samorządu zarówno samorządu terytorialnego, jak i samorządu gospodarczego, mimo że będą to różne rodzaje samorządu. Taka interpretacja prowadzi do uznania zgodności art. 17 Konstytucji RP zarówno z ustawami regulującymi samorządy zawodowe, jak i z ustawami regulującymi inne samorządy (nie tylko samorząd gospodarczy ${ }^{26}$ ), ponieważ będą to różne rodzaje samorządu. Skutkiem tego będzie również i ten wniosek, że obecnie Konstytucja RP nie utożsamia pojęcia samorządu jedynie z podmiotem wykonującym administrację publiczną.

Artykuł 17 ust. 2 zdanie 2 Konstytucji RP wprost wskazuje, że ,inne rodzaje samorządu" nie mogą naruszać wolności wykonywania zawodu ani ograniczać wolności podejmowania działalności gospodarczej. Takie sformułowanie powołanego przepisu wyraźnie dotyczy samorządu gospodarczego albo samorządu, którego członkami są przedsiębiorcy. Poprzez negatywne określenie, jakimi sprawami nie mogą zajmować się samorządy objęte terminem ,inny rodzaj samorządu", w istocie ustawodawca wykluczył możliwość powierzania im zadań publicznych, a przynajmniej ich istotniejszej części. Jeżeli samorząd gospodarczy ma obejmować przedsiębiorców, to zrozumiałym byłoby przyznanie prawa do wykonywania zadań w zakresie działalności gospodarczej, każde zaś przyznane w tym zakresie zadanie mogłoby ingerować w wolność albo wykonywania zawo-

26 Na przykład samorząd zawodowy niektórych przedsiębiorców - ustawa z dnia 30 maja 1989 roku o samorządzie zawodowym niektórych przedsiębiorców (Dz.U. z 1989 r. Nr 35, poz. 194 ze zm.). 
du, albo podejmowania i wykonywania działalności gospodarczej. Ustrojodawca nawet nie przyznał takiemu samorządowi prawa do reprezentacji przedsiębiorców (jak zrobiono to w przypadku samorządu zawodowego).

Sama nazwa ,samorząd gospodarczy” mimo jej braku w art. 17 ust. 2 Konstytucji RP pojawia się w art. 61 ustawy zasadniczej w zakresie regulacji zasady jawności obejmującej prawo każdego obywatela dostępu do informacji pochodzących od organów samorządu gospodarczego w zakresie wykonywania władzy publicznej lub gospodarowania mieniem publicznym. Wydaje się, że to nie art. 61 ust. 1 Konstytucji RP, ale art. 17 ust. 2 Konstytucji RP określa pozycję samorządu gospodarczego jako podmiotu, którego ustrojodawca nie zalicza do kategorii podmiotów wykonujących zadania publiczne. Art. 61 ust. 1 Konstytucji RP reguluje zasadę jawności i tylko w zakresie tej zasady należy interpretować ten przepis ${ }^{27}$.

\section{Dopuszczalność przekazania izbom gospodarczym zadań publicznych w drodze rozporządzenia}

Analizując zadania izb gospodarczych pod kątem ingerencji w podejmowanie i prowadzenie działalności gospodarczej, musimy stwierdzić, że nawet te $\mathrm{z}$ tych zadań, które mogłyby być samodzielnie interpretowane jako pozwalające na jakąkolwiek ingerencję, nie mogą podlegać takiej wykładni, ponieważ treść art. 17 ust. 2 zd. 2 Konstytucji RP nie dopuszcza takiego kierunku interpretacji. Przykładowo zapisane $\mathrm{w}$ art. 2 u.i.g. prawo do reprezentowania przez izbę gospodarczą interesów gospodarczych zrzeszonych w niej przedsiębiorców nie może w żaden sposób ani narzucać tym przedsiębiorcom zakresu lub formy prowadzenia działalności gospodarczej, ani też ograniczać ustawowo przyznanej swobody w prowadzeniu tej działalności przez jakąkolwiek formę jej regulowania. Analogicznie kształtowanie i upowszechnianie przez izbę gospodarczą zasad etyki w działalności gospodarczej, w tym norm rzetelnego postępowania w obrocie gospodarczym, nie może prowadzić do ograniczenia $\mathrm{w}$ działalności gospodarczej nawet tego przedsiębiorcy, który owe zasady narusza.

$\mathrm{W}$ tym zakresie należy zwrócić uwagę na art. 5 ust. 3 u.i.g. Zgodnie z tym przepisem na wniosek lub za zgodą izby gospodarczej Rada Ministrów może, w drodze rozporządzenia, powierzyć tej izbie wykonywanie niektórych zadań zastrzeżonych w przepisach prawa dla administracji państwowej.

Tak zawarta delegacja ustawowa nie została dotychczas wykorzystana i wydaje się, że trudność sprawiałoby skorzystanie z niej po wejściu w życie Konstytucji RP. Rada Ministrów na podstawie art. 146 ust. 4 pkt 2 Konstytucji RP posia-

27 Inaczej wydaje się Z. Leońskiemu (Zasada wolności gospodarczej a samorząd gospodarczy, [w:] Spór o samorząd gospodarczy w Polsce, red. S. Wykrętowicz, Poznań 2005, s. 78). 
da kompetencje do wydania rozporządzenia wykonawczego do ustawy. Zgodnie $\mathrm{z}$ art. 92 ust. 1 Konstytucji RP upoważnienie powinno zawierać określenie organu właściwego do jego wydania, zakres spraw przekazanych do uregulowania i wytyczne dotyczące treści aktu.

Zawarte $\mathrm{w}$ art. 5 ust. 3 u.i.g. upoważnienie $\mathrm{w}$ istocie stanowi upoważnienie blankietowe ${ }^{28}$, ponieważ pozwala Radzie Ministrów na przekazanie izbom gospodarczym dowolnych zadań publicznych wykonywanych przez administrację publiczną, a jedynym ich sprecyzowaniem jest zwrot „niektórych”. Nie zawiera w szczególności wskazania, jaki charakter mają mieć te zadania, w jakich sferach mają one się mieścić (czy w zakresie gospodarki, czy poza tym zakresem?). Wykonanie tej delegacji ustawowej nie zawiera żadnych ograniczeń treściowych i w zasadzie pozwala na pełną dowolność ustalania zadań, które byłyby przekazywane przez Radę Ministrów izbie gospodarczej. Taka zaś „ogólność” sformułowań zawartych w delegacji ustawowej do wydania rozporządzenia jest traktowana w doktrynie jako niezgodna $z$ art. 92 ust. 2 Konstytucji RP29.

Jak wprost stwierdził TK w jednym $\mathrm{z}$ wyroków, prawidłowe upoważnienie ustawowe musi mieć charakter szczegółowy pod względem: 1) podmiotowym (musi określać organ właściwy do wydania rozporządzenia), 2) przedmiotowym (musi określać zakres spraw przekazanych do uregulowania) oraz 3) treściowym (musi określać wytyczne dotyczące treści aktu) ${ }^{30}$. Co istotne, wytyczne nie mogą dotyczyć samej procedury wydania rozporządzenia ${ }^{31}$. Ponadto zakres materii, która może być przekazana ustawą do regulacji w rozporządzeniu, powinien zostać określony ,poprzez wskazanie spraw rodzajowo jednorodnych z tymi, które reguluje ustawa, lecz które nie mają zasadniczego znaczenia z punktu widzenia założeń ustawy i dlatego nie zostały unormowane w niej wyczerpująco, a są niezbędne do realizacji norm ustawy" 32 . Trudno uznać, aby art. 5 ust. 3 u.i.g. zawierał treść niezbędną do realizacji ustawy o izbach gospodarczych.

Także zgodnie z $\S 63$ rozporządzenia w sprawie zasad techniki prawodawczej $^{33}$, przepis upoważniający do wydania rozporządzenia winien wskazywać: organ właściwy do wydania rozporządzenia, rodzaj aktu, zakres spraw przekazy-

28 Zob. wyrok TK z dnia 17 marca 2015 roku, sygn. K 31/13, OTK-A 2015/3/31; wyrok TK z dnia 17 lipca 2014 roku, sygn. K 59/13, OTK-A 2014/7/73.

29 Por. M. Żabicka-Kłopotek, ,Wytyczne” jako element upoważnienia do wydawania rozporzadzenia (na tle art. 92 Konstytucji RP), „Przegląd Sejmowy” 2006, nr 3, s. 30.

${ }^{30}$ Wyrok TK z dnia 18 grudnia 2014 roku, sygn. K 33/13, OTK-A 2014/11/120; wyrok TK z dnia 8 stycznia 2013 roku, sygn. K 38/12, OTK-A 2013/1/1.

31 Por. wyrok TK z dnia 26 października 1999 roku, sygn. K 12/99, OTK 1999/6/120; wyrok TK z dnia 29 maja 2002 roku, sygn. P 1/01, OTK-A ZU 2002/3/36; M. Żabicka-Kłopotek, op. cit., s. 32; K. Spryszak, Upoważnienie do wydania rozporzadzenia - model konstytucyjny i jego interpretacje, „Przegląd Prawa Publicznego” 2019, nr 10, s. 57-58.

32 Wyrok TK z dnia 8 stycznia 2013 roku...

33 Rozporządzenie Prezesa Rady Ministrów z dnia 20 czerwca 2002 roku w sprawie „Zasad techniki prawodawczej" (Dz.U. z 2016 r. poz. 283). 
wanych do uregulowania w rozporządzeniu i wytyczne dotyczące treści rozporządzenia. Są to więc cztery odrębne elementy.

Delegacja ta ma charakter ogólny, pozwalający Radzie Ministrów na dowolne ustalenie, które zadania wykonywane przez administrację publiczną mogłyby być przekazywane izbom gospodarczym, czym ingerowano by w kompetencje ustawodawcy uprawnionego do określenia, jakie organy administracji rządowej wykonują określone zadania ${ }^{34}$.

W każdym przypadku, gdy ustawodawca zamierza upoważnić organ administracji publicznej do powierzania kompetencji publicznoprawnych izbom gospodarczym, wprowadza odrębne delegacje ustawowe, zawierające dużo bardziej precyzyjną delegację. Przykładem są art. 26 i art. 32 ustawy o transporcie drogowym $^{35}$, zgodnie z którymi minister właściwy do spraw transportu może upoważnić do wydawania zezwoleń zagranicznych na przewóz osób i rzeczy, w drodze rozporządzenia, polskie organizacje o zasięgu ogólnokrajowym zrzeszające międzynarodowych przewoźników drogowych, uwzględniając właściwe zabezpieczenie dokumentów związanych z wydawaniem tych zezwoleń uniemożliwiające dostęp do nich osób niepowołanych, wyposażenie pomieszczeń w urządzenia gwarantujące bezpieczeństwo przechowywanych dokumentów, ubezpieczenie od wszelkiego ryzyka oraz sposób rozliczania się w przypadku zaginięcia, zniszczenia lub utraty tych dokumentów.

Takimi organizacjami, którym wyżej wymieniony minister przekazał kompetencję do wydawania wzmiankowanych zezwoleń, są: Polska Izba Gospodarcza Transportu Samochodowego i Spedycji z siedzibą w Warszawie oraz Sądecka Izba Gospodarcza z siedzibą w Nowym Sączu ${ }^{36}$.

\section{Krajowa Izba Gospodarcza}

Krajowa Izba Gospodarcza (KIG) stanowi jedną z form samorządu gospodarczego. Regulacja KIG jest zbieżna z regulacją pozostałych izb gospodarczych, ale z pewnymi wyjątkami. Odmiennie od pozostałych izb gospodarczych przedstawia się skład KIG. O ile członkami izb gospodarczych są przedsiębiorcy, o tyle w skład KIG wchodzą izby gospodarcze oraz te pozostałe organizacje społecz-

34 Por. B. Banaszak, Egzekutywa w Polsce - stan obecny i uwagi de lege fundamentali ferenda, „Przegląd Sejmowy” 2006, nr 3, s. 20.

35 Ustawa z dnia 6 września 2001 roku o transporcie drogowym (Dz.U. z 2019 r. poz. 2140 ze zm.).

${ }^{36}$ Pkt 12 i 15 załącznika do rozporządzenia Ministra Infrastruktury z dnia 5 lipca 2011 roku w sprawie upoważnienia polskich organizacji o zasięgu ogólnokrajowym zrzeszających międzynarodowych przewoźników drogowych do wydawania zezwoleń zagranicznych (Dz.U. z 2011 r. $\mathrm{Nr}$ 146, poz. 869). 
ne i gospodarcze, których celem jest wspieranie rozwoju gospodarczego (art. 11 ust. 1 u.i.g.). Wspólny jest dobrowolny charakter członkostwa oraz zadania objęte art. 5 u.i.g. (art. 11 ust. 1 i art. 12 ust. 1 u.i.g.). Mimo dobrowolności zrzeszania się w KIG ustawodawca zlikwidował z dniem 8 czerwca 1989 roku Polską Izbę Handlu Zagranicznego wprowadzając jednocześnie obowiązek przejęcia przez KIG wszelkich spraw, zobowiązań i majątku dotychczasowej Polskiej Izby Handlu Zagranicznego.

Ustawa o izbach gospodarczych określiła przede wszystkim zadania, ale i kompetencje KIG. Należą do nich:

a) reprezentowanie wspólnych interesów gospodarczych zrzeszonych członków (art. 11 ust. 2 u.i.g.);

b) przyczynianie się do tworzenia warunków rozwoju życia gospodarczego oraz wspierania inicjatyw gospodarczych członków (art. 12 ust. 1 w związku $\mathrm{z}$ art. 5 ust. 2 pkt 1 u.i.g.);

c) popieranie, we współpracy z właściwymi organami oświatowymi, rozwoju kształcenia zawodowego, wspieranie nauki zawodu w zakładach pracy oraz wspieranie doskonalenia zawodowego na przykład poprzez certyfikację szkoleń, a także prowadzenie szkoleń adresowanych do przedsiębiorców (art. 12 ust. $1 \mathrm{w}$ związku z art. 5 ust. 2 pkt 2 u.i.g.);

d) delegowanie swoich przedstawicieli, na zaproszenie organów państwowych, do uczestniczenia w pracach instytucji doradczo-opiniodawczych w sprawach działalności wytwórczej, handlowej, budowlanej i usługowej (art. 12 ust. $1 \mathrm{w}$ związku $\mathrm{z}$ art. 5 ust. 2 pkt 3 u.i.g. $)^{37}$;

e) organizowanie i stwarzanie warunków do rozstrzygania sporów w drodze postępowania polubownego i pojednawczego oraz uczestniczenie na odrębnie określonych zasadach w postępowaniu sądowym w związku z działalnością gospodarczą jej członków wraz z powołaniem Kolegium Arbitrów do rozstrzygania sporów wynikłych w związku ze współpracą gospodarczą z zagranicą, poddanych orzecznictwu Kolegium Arbitrów, jak również opracowywanie i doskonalenie zasad etyki obowiązującej przedsiębiorców (art. 12 ust. $1 \mathrm{w}$ związku z art. 5 ust. 2 pkt 4 u.i.g. oraz art. 12 ust. 4 pkt 4 u.i.g.);

f) wydawanie opinii o istniejących zwyczajach dotyczących działalności gospodarczej (art. 12 ust. $1 \mathrm{w}$ związku z art. 5 ust. 2 pkt 5 u.i.g.);

37 Przykładowo KIG ma prawo do: a) zgłoszenia przedstawicieli do Rady Dostępności jako organu opiniodawczo-doradczego przy ministrze właściwym ds. rozwoju regionalnego (art. 13 ust. 1, ust. 4 pkt 6 ustawy z dnia 19 lipca 2019 roku o zapewnianiu dostępności osobom ze szczególnymi potrzebami, Dz.U. z 2020 r. poz. 1062); b) wskazania Ministrowi Edukacji Narodowej przedstawiciela powołanego do składu Rady Interesariuszy Zintegrowanego Systemu Kwalifikacji (§ 1 pkt 1 zarządzenia nr 24 Ministra Edukacji Narodowej z 6 sierpnia 2020 roku w sprawie powołania członków Rady Interesariuszy Zintegrowanego Systemu Kwalifikacji na kadencję w latach 2020-2024, Dz. Urz. MEN z 2020 r. poz. 24). 
g) informowanie o funkcjonowaniu przedsiębiorców oraz wyrażanie opinii o stanie rozwoju gospodarczego na obszarze działania izby (art. 12 ust. 1 w związku z art. 5 ust. 2 pkt 6 u.i.g.);

h) utworzenie funkcjonalnie i organizacyjnie wyodrębnionej Polskiej Izby Handlu Zagranicznego dla wykonywania wspólnych zadań w zakresie promocji handlu zagranicznego oraz określenie zasad bezpośredniej współpracy Polskiej Izby Handlu Zagranicznego z przedsiębiorcami w zakresie handlu zagranicznego (art. 12 ust. 2 i ust. 3 u.i.g.);

i) organizowanie wystaw oraz międzynarodowych targów w kraju i za granicą (art. 12 ust. 4 pkt 1 u.i.g.);

j) współpracowanie z organizacjami międzynarodowymi i zagranicznymi oraz uczestniczenie w nich, jeżeli nie narusza to zobowiązań wynikających z umów międzynarodowych, w których Rzeczpospolita Polska jest stroną, a także tworzenie za zgodą ministra właściwego do spraw zagranicznych i ministra właściwego do spraw gospodarki swoje przedstawicielstwa zagraniczne (art. 12 ust. 4 pkt 2 u.i.g.);

k) wykonywanie czynności izb przemysłowo-handlowych na podstawie umów między Rzecząpospolitą Polską lub kontrahentem polskim a obcymi państwami lub kontrahentami albo na podstawie międzynarodowych zwyczajów handlowych, a zwłaszcza uwierzytelnianie dokumentów oraz wydawanie certyfikatów, świadectw i zaświadczeń (art. 12 ust. 4 pkt 3 u.i.g.);

1) wystawianie świadectw potwierdzających niepreferencyjne pochodzenie towarów wywożonych z terytorium Polski ${ }^{38}$ (art. 12 ust. 5 u.i.g.);

m) inicjowanie i tworzenie na terytorium Rzeczypospolitej Polskiej dwu- lub wielostronnych izb gospodarczych oraz określanie liczby członków założycieli wymaganej do utworzenia izby (art. $12^{1}$ ust. 1 u.i.g.).

Powyższy katalog nie jest wyczerpujący, ale zawiera jedną istotną kompetencję. Zgodnie z art. 12 ust. 5 u.i.g. KIG została ustawowo upoważniona do wystawiania świadectw potwierdzających niepreferencyjne pochodzenie towarów, o których mowa w art. 10 ust. 2 Prawa celnego. Powołany przepis pozwala na wystawianie takich świadectw przez inne niż organy administracji celnej podmioty upoważnione na podstawie odrębnych ustaw. Pomijając częściową zbędność podwójnego ustawowego upoważnienia (art. 10 ust. 2 Prawa celnego pozwala ustawodawcy na upoważnienie innych niż organy celne podmiotów, a art. 12 ust. 5 u.i.g. zawiera ustawowe upoważnienie dla KIG do wystawania takich świadectw), to nie budzi wątpliwości, że powołany przepis ustawy o izbach gospodarczych przyznał ustawowo KIG kompetencję publicznoprawną obejmującą prawo do wydawania dokumentu (świadectwa niepreferencyjnego pochodzenia

38 Świadectwa niepreferencyjnego pochodzenia towarów, o których mowa w art. 10 ust. 2 ustawy z dnia 19 marca 2004 roku - Prawo celne (Dz.U. z 2020 r. poz. 1382), obejmujące pochodzenie towarów, o którym mowa w art. 59-63 rozporządzenia Parlamentu Europejskiego i Rady (UE) Nr 952/2013 z dnia 9 października 2013 roku ustanawiające unijny kodeks celny (Dz.U.UE.L.2013.269.1), dotyczące towarów wywożonych z terytorium kraju. 
towaru) w imieniu własnym tego podmiotu. Przedsiębiorca będący eksporterem lub nadawcą towaru może więc wybrać, czy zamierza uzyskać takie świadectwo o organu administracyjnego, czy od podmiotu wykonującego w tym zakresie administrację publiczną.

Ponadto odrębne ustawy nakładają na rzecz organów KIG dodatkowe kompetencje o charakterze publicznoprawnym.

Taka regulację zawiera art. $255 \S 1$ b i $\S 1$ c Kodeksu morskiego ${ }^{39}$ oraz $\S 3$ i 5 rozporządzenia Ministra Infrastruktury w sprawie powoływania dyspaszerów oraz postępowania dyspaszerskiego ${ }^{40}$, zawierająca uprawnienie dla Prezesa KIG do powoływania w porozumieniu z ministrem właściwym ds. gospodarki morskiej dyspaszerów i wpisywania oraz skreślania ich z listy dyspaszerów ${ }^{41}$.

\section{Tworzenie izb dwustronnych i wielostronnych}

KIG ma prawo do udziału w tworzeniu izb gospodarczych dwustronnych i wielostronnych. Izby dwustronne lub izby wielostronne to odrębne podmioty posiadające własna osobowość prawną, zrzeszające przedsiębiorców co najmniej z dwóch państw: z Polski i przynajmniej z jednego innego państwa. Wprawdzie podział na izby dwustronne i wielostronne nie został określony w ustawie o izbach gospodarczych; tym niemniej jest on czytelny. Izba gospodarcza dwustronna to taka, która zrzesza przedsiębiorców z Polski i jednego innego kraju; izba gospodarcza wielostronna to taka, która zrzesza przedsiębiorców z Polski i co najmniej dwóch innych państw ${ }^{42}$.

Tryb i przesłanki tworzenia dwustronnych lub wielostronnych izb gospodarczych zostały w sposób fragmentaryczny uregulowane przede wszystkim w ustawie o izbach gospodarczych. Zgodnie $\mathrm{z}$ art. $12^{1}$ ust. 1 u.i.g. KIG ma wyłączne prawo inicjowania tworzenia na terytorium RP obu wyżej wymienionych izb ${ }^{43}$, przy czym wszczęcie procedury tworzenia tych izb powinien wynika $\mathrm{z}$ wniosku zainteresowanych przedsiębiorców.

39 Ustawa z dnia 8 września 2001 roku Kodeks morski (Dz.U. z 2018 r. poz. 2175 ze zm.).

40 Rozporządzenie Ministra Infrastruktury z dnia 14 kwietnia 2004 roku w sprawie powoływania dyspaszerów oraz postępowania dyspaszerskiego (Dz.U. z 2004 r. Nr 109, poz. 1158).

41 Dyspaszerem jest osoba ustalająca (rzeczoznawca) na zlecenie armatora, czy zachodzi awaria wspólna, oblicza wysokości strat awarii wspólnej i ich rozdzielenia — art. $255 \S 1$ Kodeksu morskiego. Sporządzona przez dyspaszera dyspasza ma jednak charakter ekspertyzy, a nie aktu rozstrzygającego; por. M.A. Nesterowicz, [w:] Kodeks morski. Komentarz, red. D. Pyć, I. Zużewicz-Wiewiórowska, LEX/el. 2012, komentarz do art. 255.

${ }^{42}$ K. Bandarzewski, op. cit., s. 238-241.

43 Prezydium KIG uregulowało ten tryb w uchwale z 21 listopada 2002 roku, nr 41/11/2002 w sprawie trybu inicjowania tworzenia na terytorium Rzeczypospolitej Polskiej dwu- lub wielostronnych izb gospodarczych i określenia liczby założycieli tych izb; za: ibidem, s. 237-241. 
Zgodnie z art. $12^{1}$ ust. 4 u.i.g. członkami izb mogą być przedsiębiorcy w rozumieniu przepisów Prawa przedsiębiorców ${ }^{44}$ oraz przedsiębiorcy zagraniczni w rozumieniu przepisów ustawy o zasadach uczestnictwa przedsiębiorców zagranicznych i innych osób zagranicznych w obrocie gospodarczym na terytorium Rzeczypospolitej Polskiej ${ }^{45}$.

Wprawdzie zgodnie $\mathrm{z}$ art. $12^{1}$ ust. 3 u.i.g. utworzenie takich izb odbywa się na zasadach określonych w ustawie o izbach gospodarczych, ale jest to odesłanie tylko częściowo prawidłowe. Artykuł 7 ust. 1 u.i.g. określa minimalną liczbę założycieli izb gospodarczych, natomiast zgodnie z art. $12^{1}$ ust. 1 zdanie 2 u.i.g. to KIG określa liczbę członków założycieli wymaganą do utworzenia takich izb. Prezydium KIG uregulowało tryb i warunki tworzenia dwustronnych i wielostronnych izb gospodarczych i przepisy tej uchwały regulują nie tylko wymagania co do liczby założycieli, ale i treść wniosku i załączników do wniosku o wszczęcie procedury utworzenia takich izb oraz określa w jakich okolicznościach KIG nie wyraża zgody na utworzenie izby. Ponadto wniosek o utworzenie izby podlega ocenie KIG zarówno pod względem legalności, jak i zasadności. Zgodnie z art. $12^{1}$ ust. 5 u.i.g. wyłącznym prawem KIG jest także złożenie wniosku do KRS o zarejestrowanie izby dwustronnej lub wielostronnej.

Powyższe wskazuje, że ustawodawca upoważnił KIG do częściowego uregulowania istotnych elementów procedury tworzenia izb dwustronnych oraz wielostronnych. Przy czym istotnym jest to, że upoważniono KIG do regulacji takiej materii, która ma charakter ustawowy jak na przykład określenie minimalnej liczby założycieli danych izb ${ }^{46}$. Wyraźnie kontrastuje to na przykład z art. 7 ust. 1-1b u.s.g., w którym dla pozostałych izb gospodarczych ustawodawca uregulował minimalną liczbę założycieli.

\section{Zakończenie}

Przeprowadzona analiza obowiązującego ustawodawstwa wskazuje na brak koncepcji regulacji samorządu gospodarczego. Niewątpliwie w 1989 roku, kiedy tworzono regulacje dotyczące wolnej gospodarki rynkowej, wprowadzanie obligatoryjnego samorządu gospodarczego mogło być traktowane jako inna forma ingerencji w samodzielność przedsiębiorców. Tym niemniej, podczas przygotowywania Konstytucji RP należało w sposób dalekosiężny określić koncepcję

${ }^{44}$ Definicję przedsiębiorców zawiera art. 4 ust. 1 i ust. 2 ustawy z 6 marca 2018 roku Prawo przedsiębiorców (Dz.U. z 2021 r. poz. 162).

45 Definicję przedsiębiorcy zagranicznego zawiera art. 3 pkt 7 ustawy z dnia 6 marca 2018 roku o zasadach uczestnictwa przedsiębiorców zagranicznych i innych osób zagranicznych w obrocie gospodarczym na terytorium Rzeczypospolitej Polskiej (Dz.U. z 2020 r. poz. 1252).

46 K. Bandarzewski, op. cit., s. 238, 240. 
samorządu gospodarczego. Istniejący art. 17 ust. 2 Konstytucji RP nie pozwala na zakwalifikowanie samorządu gospodarczego jako części zdecentralizowanej administracji publicznej, tworzonej celem wykonywania zadań publicznych, a w szczególności uniemożliwia ustawowe przyznanie izbom gospodarczym uprawnień w zakresie ingerowania w wolność podjęcia i wykonywania działalności gospodarczej ${ }^{47}$. Brak jednoznaczności ustrojodawcy w zaliczeniu samorządu gospodarczego do kategorii podmiotów władzy publicznej powinien skutkować rezygnacją z obecnej treści art. 17 ust. 2 Konstytucji RP.

Bliższa analiza obowiązującego ustawodawstwa wskazuje jednak, że samorząd gospodarczy wykonuje, aczkolwiek nieliczne, zadania publiczne, i to nawet takie, które ingerują w prowadzenie działalności gospodarczej poprzez prawo na przykład do wydawania zezwoleń.

Ponadto wyjątkowo KIG uzyskała prawo do regulowania — w zakresie osób prawnych stanowiących dwu- lub wielostronne izby gospodarcze - materii ustawowej. Także wyjątkowy charakter PIG bardziej zbliżą ją bardziej do publicznego organu administrującego niż stowarzyszenia przedsiębiorców.

Powyższe prowadzi do wniosku, że aktualnie samorząd gospodarczy jest na etapie sprawdzania przez ustawodawcę, w jaki sposób wykona powierzane mu zadania. Co do zasady to prawidłowa droga. Sami przedsiębiorcy powinni przekonać się, czy określone zadania publiczne mogą być wykonywane skuteczniej i bardziej prawidłowo przez samorząd gospodarczy niż na przykład administrację rządową lub samorządu terytorialnego. W ten sposób oddolnie buduje się potrzebę „przekazywania” zadań na rzecz istniejących organizacji gospodarczych. Dopiero stwierdzenie, że w praktyce skutecznie wykonują zadania te właśnie organizacje, powinno, zgodnie z zasadą pomocniczości, skutkować radykalniejszym przekazywaniem zadań na rzecz samorządu i być może w dłuższej perspektywie także na włączenie samorządu gospodarczego do struktury publicznych podmiotów administrujących. Problematyczna pozostanie wówczas dotychczasowa regulacja art. 17 ust. 2 Konstytucji RP.

Budowy samorządu gospodarczego jako części struktury administracji publicznej nie powinno się dokonywać w sposób odgórny, podyktowany samym założeniem potrzeby czy wyższości samorządu gospodarczego mającego charakter publiczny nad samorządem niemającym takiego charakteru ${ }^{48}$. Wydają się przedwczesne te poglądy w doktrynie, które wskazują na konieczność tworzenia samorządu gospodarczego jako publicznych podmiotów administrujących ${ }^{49}$.

47 Za dopuszczalnością takieto rozwiązania opowiedziano się w doktrynie por. M. Jurewicz, Ustrój prawny izb gospodarczych - propozycje jego usprawnienia, „Studia Prawno-Ekonomiczne” 79, 2009, s. 127.

48 Por. np. S. Wykrętowicz, Funkcjonowanie samorzadu gospodarczego w wybranych krajach europejskich, [w:] Funkcjonowanie samorzadu gospodarczego w wybranych krajach europejskich, Warszawa 2013, s. 13-14; R. Kmieciak, op. cit., s. 97-102.

49 M. Stahl, op. cit., s. 517; Z. Leoński, op. cit., s. 78-79; M.A. Waligórski, op. cit., s. 96. 
W szczególności wątpliwym jest nieraz podnoszona teza o większej efektywności i konkurencyjności gospodarek tych państw, które posiadają obligatoryjny dla przedsiębiorców samorząd gospodarczy ${ }^{50}$. Takiego samorządu nie ma na przykład w USA, Kanadzie, Australii, Wielkiej Brytanii czy państwach skandynawskich, a kraje te trudno uznać za słabo rozwinięte.

Ponadto należałoby bliżej przyjrzeć się doświadczeniom innych państw, w których samorząd istnieje jako struktura władzy publicznej i samorząd jako struktura prywatnoprawna oraz na tej podstawie dokonać wszechstronnej oceny „zysków i strat” obu tych form. W doktrynie zachodnioeuropejskiej wskazuje się bowiem na istotne wady i zalety obu tych form. Samorząd gospodarczy w modelu anglosaskim traktowany jest jako bardziej sprawna formuła pomagająca przedsiębiorcom, między izbami występuje konkurencja wzmagająca potrzebę większej efektywności i otwartości dla przedsiębiorców ${ }^{51}$. Model kontynentalny z jednej strony zapewnia reprezentację ogółu przedsiębiorców, ale z drugiej jest z założenia mniej dynamiczny niż anglosaski, ponieważ tworząc strukturę obligatoryjną dla przedsiębiorców, izby te nie muszą w sposób ciągły dostosowywać się do potrzeb przedsiębiorców ${ }^{52}$.

Pozostaje otwartym pytanie, czy dla polskich przedsiębiorców bardziej atrakcyjny (czyli skuteczniej pomagający im w prowadzeniu działalności gospodarczej) byłby model kontynentalny z przymusowym członkostwem i ze stałymi zadaniami publicznymi wykonywanymi na rzecz przedsiębiorców, czy też istniejący model anglosaski z fakultatywnym członkostwem i z założenia brakiem zadań publicznych, ponieważ w tym zakresie przede wszystkim podstawowe znaczenie miałoby stanowisko samych przedsiębiorców.

Polski ustawodawca nie powinien powielać błędów znanych w innych rozwiązaniach prawnych, lecz wykorzystać najlepsze wzorce celem dostosowania ich do warunków, w jakich polscy przedsiębiorcy prowadzą działalność.

Rekapitulując, musimy stwierdzić, że izby gospodarcze zostały przez ustawodawcę zaliczone do modelu anglosaskiego samorządu gospodarczego i w związku z tym nie stanowią części decentralizacji władzy publicznej. Tym niemniej przekazywane są izbom niektóre zadania publiczne analogicznie jak organizacjom pozarządowym. Wyposażanie izb gospodarczych w trwały zakres zadań publicznych może doprowadzić do włączenia samorządu w strukturę władzy wykonawczej, ale wymagałoby to zmiany art. 17 ust. 2 Konstytucji RP.

50 Por. np. A. Arendarski, Samorząd gospodarczy będzie zwieńczeniem transformacji, „Magazyn Teraz Polska” 2014, nr 2, s. 59.

51 K. Bandarzewski, op. cit., s. 297; M. Pilgrim, R. Meier, National Chambers of Commerce. A primer on the organizational and role of chambers system, Bonn 1995, s. 53.

52 K. Bandarzewski, op. cit., s. 296-299. 


\section{Bibliografia}

Arendarski A., Samorząd gospodarczy będzie zwieńczeniem transformacji, „Magazyn Teraz Polska” 2014, $\mathrm{nr} 2$.

Banaszak B., Egzekutywa w Polsce - stan obecny i uwagi de lege fundamentali ferenda, „Przegląd Sejmowy" 2006, nr 3.

Bandarzewski K., Samorząd gospodarczy w prawie polskim. Studium prawne, Kraków 2014.

Biernat S., Administracyjnoprawne zasady podejmowania działalności gospodarczej (de lege lata i de lege ferenda), [w:] Księga Pamiątkowa Profesora Eugeniusza Ochendowskiego, Toruń 1999.

Bigo T., Związi publiczno-prawne w świetle ustawodawstwa polskiego, Warszawa 1928.

Bilancia P., Pizzetii F., Chambers of Commerce in Italy and in some European Union Countries: a study of functional and autonomous bodies, Roma 2000.

Błachucki M., Przemiany ustrojowe samorzadu specjalnego w polskim prawie administracyjnym, [w:] Prace stadialne Warszawskiego Seminarium Aksjologii Administracji, t. 3, Kraków 2014.

Boć J., Decentralizacja [w:] Prawo administracyjne, red. J. Boć, Wrocław 2001.

Dąbrowski K., Izby przemystowo-handlowe Drugiej Rzeczypospolitej jako instytucja samorzadu przemystowo-handlowego. Ujęcie doktrynalne i konstytucyjne, „Studia z Dziejów Państwa i Prawa Polskiego", t. 10, Kraków-Lublin-Łódź 2007.

Jastrzębski T., Samorząd gospodarczy. Izba Domów Składowych, „Przegląd Ustawodawstwa Gospodarczego" 2004, nr 10.

Jurewicz M., Ustrój prawny izb gospodarczych - propozycje jego usprawnienia, „Studia Prawno-Ekonomiczne" 79, 2009.

Kmieciak R., Antkowiak P., Walkowiak K., Samorzad gospodarczy i zawodowy w systemie politycznym Polski, Warszawa 2012.

Kmieciak R., Pozycja ustrojowa samorzadu gospodarczego w Polsce, „Studia z Polityki Publicznej” 3, 2016, nr 2 (10).

Leoński Z., Zasada wolności gospodarczej a samorząd gospodarczy, [w:] Spór o samorząd gospodarczy w Polsce, red. S. Wykrętowicz, Poznań 2005.

Nesterowicz M.A., [w:] Kodeks morski. Komentarz, red. D. Pyć, I. Zużewicz-Wiewiórowska, LEX/el. 2012.

Pawłowski S., Samorzą (organizacje) pracodawców, [w:] Samorząd zawodowy i gospodarczy, red. M.A. Waligórski, S. Pawłowski, Poznań 2005.

Pilgrim M., Meier R., National Chambers of Commerce. A primer on the organizational and role of chambers system, Bonn 1995.

Sikora K., Izby rolnicze jako forma samorządu gospodarczego w Polsce, „Studia Iuridica Lublinensia" 2012, nr 17.

Skrzydło W., Konstytucja Rzeczypospolitej Polskiej. Komentarz, LEX/el. 2013.

Spryszak K., Upoważnienie do wydania rozporzadzenia - model konstytucyjny i jego interpretacje, „Przegląd Prawa Publicznego" 2019, nr 10.

Stahl M., Zagadnienia ogólne, [w:] System Prawa Administracyjnego, t. 6. Podmioty administrujace, red. R. Hauser, Z. Niewiadomski, A Wróbel, Warszawa 2011.

Tuleja P., [w:] Konstytucja Rzeczypospolitej Polskiej. Komentarz, red. P. Tuleja, Warszawa 2019.

Waligórski M.A., Izby samorzadu gospodarczego, [w:] Prawo administracyjne ustrojowe. Podmioty administracji publicznej, red. J. Stelmasiak, J. Szreniawski, Bydgoszcz-Lublin 2002.

Wierzbowski M., Wiktorowska A., Decentralizacja i centralizacja administracji, [w:] Prawo administracyjne, red. M. Wierzbowski, Warszawa 2008.

Prawo 333, 2021

(C) for this edition by CNS 
Wykrętowicz S., Funkcjonowanie samorzadu gospodarczego w wybranych krajach europejskich, [w:] Funkcjonowanie samorzadu gospodarczego w wybranych krajach europejskich, Warszawa 2013. Żabicka-Kłopotek M., ,, Wytyczne” jako element upoważnienia do wydawania rozporządzenia (na tle art. 92 Konstytucji RP), „Przegląd Sejmowy” 2006, nr 3.

\title{
The Participation of Chambers of Commerce in the Decentralization of Public Authority
}

\begin{abstract}
Summary
Chambers of commerce are an organization associating entrepreneurs, constituting, according to the act, a form of business self-government. This self-government, unlike local one, has a varied form. Included in art. $17 \mathrm{sec} .2$ of the Constitution of the Republic of Poland, the regulation of business self-government does not allow for its classification into the category of public law entities and cannot be considered a form of decentralization of public authority. This does not prevent the occasional delegation of public tasks to chambers of commerce.
\end{abstract}

Keywords: decentralization, local self-government, business self-government, chambers of commerce, the Polish Chamber of Commerce. 